\title{
SZABADSÁG ÉS POLITIKAI RÉSZVÉTEL A REPUBLIKÁNUS ELMÉLETBEN ${ }^{1}$
}

\author{
Tóth Szilárd János \\ (BCE Politikatudományi Doktori Iskola)
}

A tanulmány beérkezett: 2018. 08. 13., opponálás: 2018. 09. 04. - 2018. 10. 17., véglegesítve: 2018. 10. 30.

\section{ÖSSZEFOGLALÓ}

\begin{abstract}
Az alábbi tanulmányban arról szólok, milyen típusú értéke van/lehet a politikai részvételnek a republikánus politikaelméleti keretben. Ebben a a legfőbb, önértékkel bíró ideált a dominancia hiányaként értett szabadság képezi. Egyfajta általános szabály, hogy szinte minden egyéb ideál, szinte minden egyéb jó a szabadság előmozdításához kapcsolódik valamilyen formában. A politikai részvétel sem képez kivételt. Ebből adódóan kerülőúton kell haladnom: a részvétel értékességére a szabadsággal való - híresen problematikus - összefüggés vizsgálatán keresztül kérdezek rá. Az összefüggésnek, ahogy majd látjuk, két értelmezési módja elterjedt. Az egyiket erốsnek vagy pedig görögnek, a másikat gyengének vagy rómainak szokás nevezni az irodalomban. A szóhasználat abból ered, hogy az előbbi értelmezés számára a legfőbb eszmetörténeti referencia a görög Arisztotelész, míg az utóbbi számára a római jog, valamint Marcus Tullius Cicero. Bővebben erről ugyanakkor nem szólok: a tanulmányom nem eszmetörténeti, hanem analitikus szempontokat követ. Míg az erősnek nevezett republikánus értelmezés a részvételnek önértéket és a szabadság szempontjából konstitutív értéket tulajdonít, addig a gyenge értelmezés szerint az összefüggés instrumentális jellegű, azaz a részvétel a szabadság fönntartásának csupán az eszköze. Implicite ezzel persze már sugalltam, hogy a két értelmezés annyiban mindenesetre megegyezik, hogy a szabadság és a politikai részvétel között logikai összefüggés van. A szabadság állapotának a fönntartása mindkét értelmezés szerint elképzelhetetlen a honpolgárok bizonyos mértékú - lehetőleg széleskörü - részvételi hajlandósága, elkötelezettsége és kollektív erőfeszítései nélkül. Röviden ismertetem, milyen rendben haladok. Először rekonstruálom a republikánus szabadságideált, eszerint a szabadság föltétele, mint majd látjuk, a dominancia hiánya. Másodszor megfogalmazok két lehetséges kritikát ezzel az ideállal szemben. Harmadszor megvizsgálom a szabadság és a politikai részvétel összefüggésének a két említett értelmezését. Nem azt állítom, hogy az egyik értelmezés igaz, a másik pedig hamis volna, éppen ellenkezőleg. Úgy látom, mindkettő magába foglal megvilágító erejú meglátásokat, mindkettő megragad valami lényegit a szabadság tekintetében.
\end{abstract}

Kulcsszavak: republikanizmus szabadság dominancia - politikai részvétel

\section{A REPUBLIKÁNUS SZABADSÁGIDEÁL}

Tanulmányom első részében rekonstruálom a republikánus szabadságideált. A legfontosabb referencia Philip Pettit politikaelméleti munkássága lesz, amely az évezredekre visszatekintő republikánus fölfogás messze legszisztematiku- 
sabb kortárs megfogalmazása. Ez ugyanakkor nem azt jelenti, hogy Pettit elmélete lenne az egyedüli referencia. Amikor a „republikánus” szabadságideálról szólok, a hagyományban a legáltalánosabban elfogadott nézetekről szólok. Jelzem, amikor nem, és azt is, amikor kifejezetten Pettit koncepcióját tárgyalom. Hogy világosabbá tegyem a gondolatmenetet, a fontosabb állításokat egy analógián keresztül szemléletem. Ez az analógia Keith Richards és a zsarnok alábbi esete lesz, melyet a nevezett önéletírásából kölcsönöztem. ${ }^{2}$

„De tudtam, hogy abban a percben, amikor kilépek az iskola ajtaján, ez a srác már ott fog rám várakozni. Egész nap azon töprengtem, hogyan juthatnék haza verés nélkül. És ez meló. A hét öt napján. Néha nem történt meg, de attól még kavarogtak a gondolataim. Hogy a frászba tudom elkerülni ezt a srácot? Semmit sem tehettem ellene, szorongtam egész nap, és emiatt egyáltalán nem tudtam semmi másra figyelni." (Keith Richards: Life. London, Weidenfeld and Nicolson. 2010.)

A szabadság állapotának azonosítása - strukturális elemzés

A republikánus fölfogás szerint, ha azonosítani kívánjuk a szabadság állapotát, egy sajátos módszerhez, a strukturális elemzés módszeréhez kell nyúlnunk. Ez azt jelenti, hogy meg kell vizsgálnunk a struktúrákat, amelyek azokat a helyzeteket, állapotokat jellemzik, amelyek közt emberi lények léteznek, majd ennek nyomán megállapítanunk, milyen mértékű szabadsággal rendelkeznek ezekben a helyzetekben, állapotokban. Milyen fontosabb elemekből állnak össze a megfigyelni kívánt helyzetek struktúrái? Nagyrészt Gerald MacCallum (1967) logikáját követve, legalább három ilyen elemet azonosíthatunk a republikánus elméletben. Egyrészt, a szabadságnak minden helyzetben vannak alanyai, másrészt, a szabadságnak minden helyzetben van potenciális tárgya, harmadrészt, minden helyzetnek vannak bizonyos föltételei, ami alatt azokat a tényezőket értem, amelyek befolyásolják a helyzetet, állapotot.

\section{A szabadság alanyai}

A szabadság alanyai egyfelől az egyének - például Keith is ilyen egyén -, másfelől pedig a különféle kollektív entitások. Utóbbi típusba sorolhatóak mind a köztársaságon belüli partikuláris kollektív entitások, mind pedig maga a köztársaság is. Értelmes lehet tehát azt firtatnunk mennyire szabad Keith nem mint Keith, hanem - mondjuk - mint a IV. c osztály tagja, ahogy azt is értelmes lehet firtatnunk, menynyiben szabad közösség a IV. c osztály a VII. b viszonylatában. Mármost a republikánus fölfogás szerint a két alanytípus szabadságigényei között szoros pozití összefüggések mutatkoznak: az egyéni szabadság semmiképpen sem választható 
el a közösségekétől, amelyekhez az egyén tartozik. Ha egy közösség szabadságát korlátozzák, az óhatatlanul kihat azoknak az egyéneknek a szabadságára is, akik ennek a közösségnek a tagságát alkotják. Így például, ha a VII. b önkényesen „megadóztatja” a IV. c-t az uzsonnapénzek elkobzásával, úgy a IV. c tagjai egyénileg is szenvednek, hiszen az „,adó” az ő egyéni befizetéseikből fog összeadódni.

Természetesen a közösségi és az egyéni szabadság közti összefüggés negatív is lehet, nem pedig csak pozitív. Minden további nélkül elképzelhető, hogy a közösségi szabadság bővülése időnként csökkentheti az egyének mozgásterét, és ugyanígy ennek fordítottja is elképzelhető, jelesül az, hogy az egyéni szabadság korlátja legyen a közösséginek. Ezek konfliktusos helyzetek, és a republikánus hagyomány bizonyos ambivalenciát mutat abban a tekintetben, hogy mely szabadságigényeknek kell primátust élvezniük. Pettit fölfogásából mindenesetre az alábbi általános irányadó elv vezethető le: amennyiben feszültség merül föl a különféle szabadságigények között, úgy a köztársaságon belüli partikuláris közösségek szabadságigényeivel szemben az egyének, a köztársasági szabadságigényekkel szemben pedig a köztársaságon belüli partikuláris közösségek szabadságinyeit kell előnyben részesíteni (Pettit, 1997: 247-257.; 2014; Andronache, 2006).

Az egyéni és a közösségi szabadság efféle összefüggése két dolgot jelent egyidejüleg. Egyfelől azt, hogy a közösségek közti, szabadságot csorbító viszonyok fölszámolása eszköze lehet az egyéni szabadság növelésének. Másfelől azt is jelenti, hogy a közösségek közti, szabadságot csorbító viszonyok fölszámolása - legalábbis Pettit republikánus fölfogása szerint - csakis abban az esetben igazolható, amennyiben nem okozza egyben az egyéni szabadság korlátozását. A IV. c közösségi szabadsága például addig, és csakis addig a pontig terjesztendő ki, ameddig a kiterjesztés nem veszélyezteti a IV. c tagjainak az egyéni szabadságát. Ismét, ahogy föntebb utaltam rá, az egyéni szabadság elsőbbségének elve inkább csak egy általános irányt szab meg Pettit elméletében. Nem kizárt, hogy adódhatnak rendkívüli helyzetek, amikor helyeselhető ideiglenesen eltérni tőle ésszerü keretek között. Modern politikai közösségekben ilyenek például azok a helyzetek, amikor a szabadságot magának a szabadságnak az érdekében szükséges korlátozni, vagy amikor komoly veszélyben forog egy-egy közösség léte természeti katasztrófa vagy járvány miatt stb. Alighanem az elv annak ellenére is fenntartható, hogy közismerten nyugati (Tully, 1995: 34.), és közismerten feszültségben van bizonyos életmódokkal és hagyományokkal (Parekh, 1992: 169.).

\section{A szabadság tárgyai}

Egy-egy alany szabadsága mindenkor potenciálisan irányul valamire: ez a valami nem más, mint bizonyos preferált, vagy potenciálisan preferált cselekvés, 
nemcselekvés, vagy cselekvéssor, esetleg állapot. Hogy preferenciákról beszélhessünk, föl kell tételeznünk, hogy az alanyunk - legyen bár egyéni vagy közösségi - releváns választási lehetőségekkel rendelkezik, hiszen ezek híján legfeljebb kényszerpályáról beszélhetnénk, de a preferált, vagy potenciálisan preferált cselekvéssorok (és egyéb szabadságtárgyak) szabad követéséről semmiképpen sem. Ez egy újabb definíciós kérdést vet föl. Milyen föltételeknek kell teljesülniük ahhoz, hogy választási lehetőségek pluralitásáról beszélhessünk? Minimális követelményekként a következőket jelölhetjük meg: lennie kell kettő vagy több választható cselekvésnek (vagy egyéb szabadságtárgynak), ezeket összeadva meg kell kapnunk a választható lehetőségek kimerítő listáját, az egyes választható lehetőségeknek pedig kölcsönösen ki kell zárniuk egymást (Pettit, 2012: 26.).

Keith előtt releváns választási lehetőség mondjuk az, hogy hazatérjen egy széles sugárúton, aztán az, hogy ehelyett hazatérjen egy kacskaringós mellékúton, az, hogy hazarepüljön helikopterrel, és esetleg még az is, hogy ne menjen haza egyáltalán, hanem inkább maradjon az iskolában. Ezek olyan választási lehetőségek, amelyek - tegyük fel - összeadva a választási lehetőségek kimerítő listáját adják. Emellett kölcsönösen ki is zárják egymást, hiszen közülük egyszerre csakis egy választható, több semmiképpen sem. Keith nem tud egyszerre a sugárúton járni és a helikopterrel repülni. Előnyben részesítheti persze egyik vagy másik választási lehetőséget, így például a hazaballagást valamelyik úton, a helikopterezést vagy esetleg az iskolában maradást. A szabadsága ezekre a lehetőségekre irányul, a ténylegesen preferált és a potenciálisan preferált cselekvéssorokra. Ezek képezik szabadsága tárgyait. Természeten nem elég, ha ténylegesen léteznek választási lehetőségek, Nem árt, ha Keith tud is róluk, máskülönben a szabadsága egykönnyen csorbát szenvedhet. Éppen elég ugyanis úgy tudnia, hogy kényszerpályán van, releváns választási lehetőségek híján ahhoz, hogy a gyakorlatban is úgy járjon el, mintha nem volnának ilyen választási lehetőségei. Ez - vagyis, hogy a szabadságnak kognitív föltételei is vannak - ebben a formában magától értetődőnek tûnik.

Egy-egy alany szabadsága persze nem csupán azt kívánja meg, hogy egyegy partikuláris választási helyzetben potenciálisan szabadon választhassa meg a követni kívánt cselekvéssort (vagy egyéb szabadságtárgyat). Keith, ha csak egyetlen területen élvez szabadságot - például szabadon mozoghat, de semmi mást szabadon meg nem tehet -, úgy nem kezelhetô szabad alanyként. A republikánus nézőpont szerint egy-egy alany szabadsága azt kívánja meg, hogy minden releváns területen szabadságot élvezzen. Hogy mégis mi számít releváns területnek, az egy híresen nehéz kérdés, és ezen a ponton nem is kívánok rá megfelelni. A kérdés egyáltalán nem csekély súlyú, hiszen, minden létező alkotmányos rend aszerint nyújt jogokat - azaz védi meg a szabad választás lehetőségét egy-egy választási helyzetben -, hogy előzetesen mit ismertünk el a szabadság leginkább releváns területeiként és tárgyaiként. 


\section{A szabadság föltétele}

Végül, a szabadság föltétele az, hogy hiányozzanak a szabadságot megszüntető vagy azt korlátozó akadályok. Mi minősülhet ilyen akadálynak? Fogalmilag legalább két módon felelhetünk meg erre a kérdésre. Egyfelől állíthatjuk azt, hogy a szabadságot fölszámoló akadály csakis a beavatkozás lehet. A szabadság föltétele ennek értelmében a beavatkozás hiánya. Másfelől állíthatjuk azt is, hogy a szabadságot fölszámoló akadály nem a beavatkozás, hanem a dominancia, következésképpen pedig a szabadság föltétele sem a beavatkozás, hanem a dominancia hiánya kell, hogy legyen. Amellett fogok érvelni, hogy ez a két nézet analitikusan elkülöníthető egymástól.

\section{Hobbes: a szabadság föltétele a beavatkozás hiánya a prefereált cselekvés esetében}

Egy, a korai modernitás idejéből, Thomas Hobbes írásaiból származó nézet szerint a szabadság föltétele az, hogy a preferált cselekvésekhez (vagy egyéb szabadságtárgyakhoz) való hozzáférést ne korlátozza senki kívülről, aktív beavatkozással (Hobbes, 1970). Eszerint amennyiben Keith-nek a sugárúton tartja kedve hazaballagni, és ebbe a zsarnok semmiféle módon bele nem avatkozik sem ennek a lehetőségnek a megszüntetésével, sem a fölcserélésével, sem pedig valamiféle megtévesztéssel - addig nincs releváns sérelem. Akkor beszélhetnénk a szabadság korlátozásáról, ha a zsarnok úgy döntene, beavatkozik, mondjuk jól megveri Keith-t, amikor a sugárútra kilép. Keith ebben az esetben nem tudna hozzáférni az általa preferált cselekvéshez: nem tudna a kedvenc útvonalán járni. Amíg azonban ilyen korlátozásra nem kerül sor, és a preferált opció beavatkozástól mentesen választható, addig a szabadság nem szenved csorbát.

Első ránézésre ez a nézet meggyőzőnek tûnik. Problémák akkor merülnek föl, ha megvizsgáljuk a lehetséges logikai következményeit. Egyfelöl például, ha a szabadság valóban csupán a preferált opcióhoz való hozzáférés szabadságát kívánja meg, abból az következik, hogy az alany még akkor is szabadnak kell, hogy minősüljön, amennyiben a preferált opció egyúttal az egyedüli hozzáférhető opció is. Föntebb láttuk, hogy ez miért volna problematikus következtetés: amennyiben hiányzik a választási lehetőségek pluralitása, az alanyunk gyakorlatilag kényszerpályán van. A másik probléma az, hogy a Hobbes-féle szabadság állapotát nem csak a preferált opcióhoz való hozzáférés megszerzése által érhetjük el, hanem úgy is, ha a preferenciáinkat egész egyszerűen hozzáigazítjuk a lehetőségeinkhez. Ez Isaiah Berlin (1990: 63.) híres kifogása. És tényleg, amennyiben Keith - miután a kedvenc útvonalát, a sugárutat lezárták előtte - megtanulja szeretni a mellékutcát, amelyet a zsarnok a számára nyitva hagyott, és ahol a továbbiakban hazatérni kénytelen, annyi- 
ban már verést sem kell eltưrnie. Hobbes fölfogásából az következne, hogy a szabadsága ezzel helyreállt. Elvégre az aktuálisan preferált opció ismét pontosan ugyanúgy hozzáférhető, mint a korábbiakban. Mindössze annyinak kellett történnie, hogy az alanyunk, Keith, meghajoljon, vagy, ahogy Marcus Aurelius (1975: 17-18.) császár fogalmaz, zúgolódás nélkül nézzen szembe a szükségszerűséggel. Ilyenformán teljesült ugyanis a szabadság föltétele, megszűnt az aktuálisan preferált opciót akadályozó beavatkozás.

\section{Berlin: a szabadság föltétele a beavatkozás hiánya minden választási lehetőség esetében}

Hobbes fölfogása tehát érzéketlen a beavatkozás hiányának az okával szemben: nem tesz minőségi különbséget az eredetileg preferált opcióhoz való hozzáférés kiharcolása és a meghunyászkodás között. Logikailag az adódik belőle, hogy Keith végső soron mindaddig szabad maradhat, ameddig a preferenciáit képes a zsarnok akaratához igazítani. Ez pedig meglehetős ellentétben áll az intuíciónkkal. Berlin nézete szerint például, aki úgy érvel, mint Hobbes, az fogalmakat téveszt össze. Mert bár igaz lehet, hogy aki külső nyomásra a preferenciáit föl tudja adni, és meg képes szeretni azt, amit ténylegesen meg is kaphat, az a boldogságát ekképpen talán megválthatja, de a szabadságát semmiképpen sem. A szabadság ugyanis minden bizonnyal többet kíván. Az aktuálisan preferált opcióhoz való szabad hozzáférés biztosítása egyszerűen nem elég. Mire van hát szükség? Berlin megoldása szerint arra, hogy a preferencia kérdését, úgy ahogy van, elválasszuk a szabadságétól. Azt kell mondanunk, lényegtelen, hogy az alanyunk melyik opciót preferálja, hiszen a szabadság nem csupán a preferált opció megnyitását kívánja, hanem az összesét. Lényegtelen, hogy Keith melyik útvonalon kíván hazatérni, ha egyáltalán haza kíván, mert csakis abban az esetben minősülhet szabad alanynak, ha egyik opció választása miatt sem kell verést elszenvednie. Másként fogalmazva, a szabadság föltétele a beavatkozás hiánya minden releváns választási lehetóség esetében.

Republikanizmus: a szabadság föltétele a dominancia hiánya

Egy ilyen, beavatkozástól mentes állapot csakis úgy lehetséges, ha a zsarnok megtartóztatja magát, a karját leengedi, a kézfejét a zsebébe csúsztatja és úgy is hagyja, függetlenül attól, hogy Keith miként dönt a hazatérésről. Ez az értelmezés is - akár a Hobbes-féle - rendelkezik bizonyos intuitív erővel. Mégis, a republikánus pozíció szerint - akár a Hobbes-féle - a belőle levezethető logikai következmények miatt nem egészen kielégítő. Jelesül, a beavatkozás hiányának Berlin általi fölfogása összeegyeztethető a beavatkozások lehetöségének 
a helyben hagyásával. Márpedig a republikánusok szerint a beavatkozások hiánya nem ér sokat, amennyiben az alanynak továbbra is tartania kell a bekövetkeztük lehetőségétől. Egy dolog ugyanis azt követelni a zsarnoktól, hogy tartóztassa magát, és egészen más dolog, hogy mondjuk el is tûnjön az iskola környékéröl. Gondoljunk bele, vajon a zsarnok puszta jelenléte az iskola környékén nem akadálya-e csakugyan már önmagában is Keith szabadságának? A republikánus felelet erre a kérdésre az, hogy hát dehogynem. A zsarnok ugyanis, amíg zsarnok, addig az, ami, és semmiként sem lehet más, mint ami. Puszta jelenléte valójában nem puszta jelenlét, hanem éppenséggel fenyegetó jelenlét. Fenyegetést az erőfölénye képez, amely akkor sem szűnik meg, amikor a kézfejét zsebbe csúsztatva megtartóztatja magát. Az erőfölény ugyanis hatalom: beavatkozási hatalom. Ameddig a zsarnok az, ami, Keith csakis abban az esetben menekedhet meg a beavatkozásoktól, ha azt a zsarnok is úgy kívánja.

A republikánus fölfogás szerint egy-egy alany pontosan akkor tekintendő szabadnak - összeszőve most már az egyes ismertetett elemeket, amelyekkel a föntebb megelőlegezett módszer, a strukturális elemzés dolgozik-, ha a helyzetben, amelyben létezik, a szabadság tárgyaihoz való hozzáférés nem függ az efféle hatalmasok jóindulatától (Viroli, 2002: 52-53.). Minden szélsőséges hatalmi egyenlőtlenség (dominancia), minden önkényes beavatkozásra lehetőséget adó ellenőrizetlen hatalom elpusztítja a szabadságot, sőt, végső soron csakis ez pusztíthatja el. Ezért hát a föltétele az egyes alanyok közti viszonylagos hatalmi egyenlőség, amely kizárja az önkényes beavatkozásokat. A szabadság állapota, ha így, azaz a dominancia hiányaként értelmezzük, nyilvánvalóan többet kíván meg, mint a beavatkozás hiánya. Nemcsak azt, hogy szabadságunkban álljon megtenni, amit kívánunk, függetlenül attól, hogy mit kívánunk, hanem azt - kölcsönvéve Pettit megfogalmazását -, hogy szabadságunkban álljon megtenni, amit kívánunk, függetlenül attól, hogy mit kívánunk, és függetlenül attól, hogy mások mit kívánnak tőlünk (Pettit, 2014: 46.). Röviden szólva azt, hogy egy sajátos (hatalmi) státust élvezzünk, a kezünkben legyen a végső kontroll egy formája a döntési helyzetekben. Politikai közösségben az ilyen állapot nyugalmat, biztonságot és kiszámíthatóságot teremt (Pettit, 1997: 90-92.).

Pettit: a szabadság három, magát a szabadságot meg nem szüntető korlátja

Ebből természetesen nem következik, hogy a szabadságnak ne volnának magát a szabadságot meg nem szüntető - korlátai. Pettit három ilyet sorol föl. Az egyik korlát a mások szabadsága. Egy-egy alany dominanciától mentes állapota nem eredményezheti egyben más alanyok dominálását. Keith szabadsága például - akár Mill híres aranyszabálya, a kárelv szerint - csakis addig terjedhet, ameddig összeegyeztethető a többi alany szabadságával. Egy másik 
korlát a szabadság területeire és tárgyaira vonatkozik. Eszerint nem egészen pontos az az általános megfogalmazás, amely szerint meg kell tudnunk tenni, amit kívánunk, függetlenül attól, hogy mit kívánunk, és függetlenül mások akaratától. Egy némiképp pontosabb megfogalmazás valahogy úgy nézne ki, hogy meg kell tudnunk tenni, amit kívánunk, függetlenül attól, hogy mit kívánunk, és függetlenül mások akaratától, de csakis a szabadság relevánsnak elismert területein, és nem másutt. Hogy mégis mi minden számít releváns területnek, utaltam már rá, az egy híresen nehéz kérdés. Pettit szerint mindenesetre föltehető, hogy a modern politikai közösségben ilyen terület a gondolaté, a lelkiismereté, a szólásé, az egyesülésé, a tulajdoné, a mozgásé, és a szabadidőé. A lista természetesen bővíthető és szúkíthető is, bár az ésszerûség keretei közt - mondja Pettit - nehéz belátni, miért volna helyes ezeket a területeket, mint egyfajta minimumot, teljes mértékben irrelevánsnak tekinteni.

Végül, a harmadik, magát a szabadságot meg nem szüntető korlátot azok a beavatkozások képezik, amelyek dominanciával nem párosulnak (Skinner, 2008). De mégis - vethetnénk föl - miként adható formális definíció arra a kérdésre, mi minden számít dominanciától mentes beavatkozásnak? A felelet a republikánus nézőpont szerint valahogy így nézne ki: azok a beavatkozások nem dominálnak - esetleg azok a beavatkozások nem önkényesek -, amelyek fölött az alanynak van kontrollja, ellenőrző hatalma, vagyis amelyek bekövetkezte nem egy domináló, erőfölényt élvező aktor önkényes döntésének a függvényei. A klasszikus - és ezért a republikánus irodalomban gyakorta előforduló - példa Odüsszeuszé. Odüsszeusz, mint ismeretes, tartva a szirének megbabonázó énekétôl, megparancsolta a matrózainak, kötözzék a hajó árbocához, és még a tulajdon kérésére se eresszék el. Odüsszeusz tudta, ha eljön az idő, a kötelet, amelyet a matrózok beavatkozása helyez rá, egyfajta korlátnak fogja érezni. Ugyanakkor azt is tudta, ezt a beavatkozást nem a matrózok önkénye, hanem a tulajdon döntése eredményezte. Vagyis - ha úgy tetszik - azt tudta, hogy a beavatkozás fölött a kontrollt megörzi. Hasonló lenne a helyzet, ha Keith megkérné az osztálytársait, négy napon keresztül vegyék el az uzsonnára szánt pénzét, hiszen fogyni kíván.

\section{KÉT KRITIKAI ELLENVETÉS}

Ez tehát a republikánus szabadságideál esszenciája. Ebben a részben két kritikát fogalmazok meg vele szemben, az egyik eszmetörténeti, a másik gyakorlati-politikai jellegú.

\section{Eszmetörténeti ellenvetés}

A kortárs republikánus szerzők - köztük Pettit - jobbára úgy szokták tartani, a beavatkozás hiányaként értett szabadság eszmetörténetileg társítható a libe- 
ralizmushoz, a dominancia hiányaként értett szabadság pedig a republikanizmushoz. Ez a társítás - azt hiszem - nem egészen megalapozott. Charles Larmore kimutatása nyomán ugyanis meggyőzőnek tûnik, hogy bár ez utóbbi értelmezést csakugyan társíthatjuk a republikánus hagyományhoz, addig korántsem magától értetődő, hogy a liberális hagyományhoz egy az egyben társíthatnánk a beavatkozás hiányaként fölfogott szabadságot. Valójában a liberális hagyomány meglehetôsen ambivalens ebben a tekintetben. Szó sincs arról, hogy a liberálisok egységesen a beavatkozás hiányaként értelmeznék a szabadságot. Éppen ellenkezőleg, ha csak két kulcsfontosságú liberális, John Locke és John Rawls írásaira gondolunk, láthatjuk, hogy ezekben a szabadság mindkét említett értelmezése előfordul (Larmore, 2001). Természetesen fölvethető, hogy itt valójában a republikánus és a liberális elemek keveredéséről van szó, ám egy ilyen igyekvés - úgy hiszem - terméketlen és szükségtelen volna. A republikánusok részéről teljesen fölösleges a bírálni kívánt liberalizmust eszmetörténetileg szegényebbnek, silányabbnak láttatni a valóságosnál.

A republikánus értelmezés érték-pluralista újrafogalmazása

A második kritikai ellenvetésem az, hogy kétséges, mennyiben vonzó normatív elmélet a republikanizmusnak az a verziója, amely szerint a szabadság állapota maradéktalanul összeegyeztethető a nem domináló beavatkozások megtûrésével. Elvégre, elvonatkoztatva Odüsszeusz és Keith emlitett egyedi példáitól, a modern politikai közösségben miként azonosíthatóak azok az állami beavatkozások - így például adók, közpolitikai intézkedések, vagy törvények -, amelyek nem dominálnak? Pettit nézete szerint ezeknek minimum három föltételnek kell megfelelniük. Egyrészt az alanyoknak egyenlő és hatékony ellenőrző hatalommal kell rendelkezniük fölöttük (Pettit, 2012: 58.), másrészt általánosan érvényes, általánosan elfogadható jogi szabályokkal kell összhangban lenniük. Harmadrészt ezek a beavatkozások nem irányulhatnak következetesen bizonyos egyének vagy csoportok ellen. Ha mindhárom föltétel érvényesül, úgy Pettit szerint a honpolgár, aki időnként számára nem tetsző beavatkozásokat kénytelen eltûrni, nem fogja azt érezni, folyton ő áll a célkeresztben, hanem csupán azt, hogy ami vele meg-megtörténik, nem több, mint "balszerencse” (tough luck) (Pettit, 2014: 142-144.).

Úgy látom, bizonyos mértékû nehézség terheli ennek a hármas föltételrendszernek a gyakorlati-politikai alkalmazását. Ez a "tough luck” érzetének a képlékenységéből adódik: ha úgy tetszik, ez az érzet nem kielégítően „tough", hiszen nehéz meghatározni - Pettit sem árulja el -, pontosan mekkora menynyiségú és milyen minőségü beavatkozások eltûrése férhet még meg vele. Föltehető, hogy a modern politikai közösségben a szabadságnak igenis vannak területei, amelyeken mindenféle beavatkozás - függetlenül attól, hogy önké- 
nyes-e vagy sem -, amennyiben minőségileg túlterpeszkedik a mások szabadságának védelmét a kárelv mentén szolgáló korlátozások körén, úgy máris egy, a szabadságot fölszámoló akadályként fog megjelenni. Nehéz persze elvi meghatározását adni annak, hogy pontosan mely területek tartoznak ide. Az mindenesetre elég valószínünek tưnik, hogy ilyen, nagyobb igényünek is nevezhető terület például a gondolkodás, a lelkiismeret, a szabadidő, de akár a szólás szabadsága is, még akkor is, ha nehéz formálisan megindokolnunk, miért pont ezek. A belátáshoz jelen helyzetben, kénytelen-kelletlen az intuíciónkra kell hagyatkoznunk. Az intuíciónkra, amely természetesen kontingens: mélységesen meghatározza az európai jogfejlődés és a liberális politikai hagyomány, amelybe beleneveledtünk. De ez talán nem szükségszerúen vesz el a fölvetett tétel igazságából. Abból tehát, hogy a szabadság korlátozásaként élnénk meg például azt, ha a közfoglalkoztatottaknak az állam megszabná, hogy hol, mely üdülőben és mikor tölthetik az éves szabadságukat. Vagy azt, ha a hatályos törvények az emberi méltóság tiszteletére hivatkozva tiltanák az újságoknak, hogy beszámoljanak a közúti balesetekről. Az efféle állami beavatkozások kétségkívül megfeleltethetőek volnának Pettit hármas feltételrendszerének. Ennek ellenére mégis - azt hiszem - a szabadság korlátozásaiként tekintenénk rájuk. Így hát, még ha el is fogadjuk nehézségként, hogy nincs a kezünkben egzakt mérce, amely segítségével megítélhetnénk, hogy a szabadságnak pontosan mely területei minősülnek nagyigényüeknek, még hihetőnek tûnhet, hogy ilyen területek léteznek.

Azt hiszem, a szabadságnak nem minden területe ilyen nagyigényú. Így például egy, a tulajdon szabadságába avatkozó progresszív adórendszer esetében, amennyiben az összhangban van Pettit hármas föltételrendszerével, alighanem még nem beszélhetünk a szabadság állapotának a veszélyeztetéséről. Ha ebben nem tévedek, és a szabadság egyes területei között csakugyan indokolt lehet az efféle differenciálás, úgy máris levonható egy lényegi következtetés. Éspedig az, hogy nagyobb normatív erővel bírna egy olyan módosított republikánus politikai ideál, amely egyfajta értékpluralista megfontolást követve (Larmore, 2001: 234.) integrálni tudná a szabadság mindkét fogalmi értelmezését. Azt is, amely a szabadság akadályát a dominanciában, és azt is, amely a beavatkozásban látja. Egy efféle értékpluralista fölfogás szerint a politikai közösségben egy-egy alany akkor tekintendő szabadnak, ha a helyzetben, amelyben létezik, a szabadság tárgyaihoz való hozzáférést egy relevánsnak elismert területen sem akadályozza dominancia, ám ezen túlmenően bizonyos nagy igényûnek tekinthetô területen beavatkozás sem, függetlenül attól, hogy az adott beavatkozás dominál-e avagy sem. Ennek a fölfogásnak az eltérése a liberális politikai ideáltól persze nem fogalmi - mint Pettit esetében -, hanem csupán hangsúlyi jellegú volna. Azaz a lényeget tekintve abban térne el, hogy a dominancia szabadságot megszüntető jellegének nem kizárólagos, csupán központi szerepet tulajdonítana, szemben a liberalizmussal, amely bár szintén 
bizonyos fokig érzékeny lehet a dominancia szabadságot korlátozó természetére, azt mégis másodlagos, kevéssé lényeges korlátként kezeli.

Megjegyzendő, hogy ez a fölvetés szoros rokonságot mutat Pettit egyes korábbi olvasóinak a kritikáival, amennyiben végső soron ugyancsak a nem domináló beavatkozások szabadságot korlátozó képességének a Pettit-féle alábecsüléséhez kapcsolódik (Wall, 2001; Patten, 1996; Brennan-Lomasky, 2006). Néhány fontos pontban azonban ezektől is eltér, éspedig, egyfelől, úgy látom, Pettitnek a nem domináló beavatkozásokkal szembeni megengedő elvi állásfoglalással nem az az igazi problémája, hogy megengedő - mint a hivatkozott Wall sugallja -, hanem az, hogy elvi. Másfelól azonban nem kívántam vitatni Pettitnek azt az álláspontját, amely szerint a dominancia és a különféle beavatkozások nem egyenlő mértékig lehetnek károsak a szabadságra nézve. Csupán azt állítottam, utóbbiak is okozhatnak bizonyos kárt. Harmadrészt elvetem azt a fölvetést, amely szerint a fönti következtetés egyben jelentéktelenné, majdhogynem semmissé teszi a republikánus és a liberális politikai ideálok közti eltérést. Ezzel szemben fenntartom, hogy az eltérés értelmes lehet, azonban - legalábbis a szabadság tekintetében - nem fogalmi, hanem hangsúlyi természetư kéne, hogy legyen. ${ }^{3}$

\section{A POLITIKAI RÉSZVÉTEL ÉRTÉKESSÉGE}

Az, hogy elfogadjuk-e a vázolt értékpluralista, a szabadság mindkét fogalmi vetületét integráló értelmezést, vagy pedig ragaszkodunk Pettit eljárásához, a továbbiak szemszögéből nézve végső soron mellékes. Mellékes, hiszen nem érinti a tanulmány harmadik részében tárgyalt fogalommal, a politikai részvétellel való összefüggést. Lényeges azonban azonosítanunk a szabadság ideáljának a pontos státusát a republikánus elméleti keretben. Jelesül, ez a státus kettős: erkölcsi egyfelől és politikai másfelől, ráadásul mindkét státusában központi. Nemcsak arról van tehát szó, mint föntebb előrebocsátottam, hogy azért tételeződik értékesnek, mert a biztonság, a nyugalom vagy tervezhető élet javainak a viszonylatában eszközértékkel bír. Ellenkezőleg, ha a republikánus politika- és erkölcselméleti keretre a maga teljességében tekintünk, a szabadság értéke mindezeken túlmutat. Éspedig, a legfőbb explicite meghatározott, önértékkel bíró ideált képezi (Pettit, 1997: 91.), amelynek az előmozdítására szinte minden egyéb ideálnak - egyebek mellett például a patriotizmusnak is (Viroli, 1995) - vissza kell utalnia.

Mit jelent az, egyfelől, hogy a szabadság erkölcsi ideál? Röviden szólva azt, hogy a középpontjában áll annak a republikánus érvelésnek, amely az igazságos, azaz erkölcsileg kívánatos rend minimális föltételeit hivatott meghatározni. Az érvelés - végső soron - leredukálható egy központi elvre, mégpedig az egyenló szabadság elvére, amely - ismét - egy elv, és mint ilyen, szembeállítható 
Rawls híres két elvével (Pettit, 2014: 102-104.). Ez az elv a lényeget tekintve azt mondja ki, hogy egy-egy rend csakis annyiban tekinthető igazságosnak, amenynyiben a tagság - vagyis a honpolgárok közössége - számára egyenlően biztosítani tudja a dominancia hiányaként értett szabadság állapotát (Pettit, 2014: 77.). Mit jelent az, másfelől, hogy a szabadság politikai ideál? Ismét röviden szólva azt, hogy a jó állam kérdése a republikánus keretben elválaszthatatlanul összefügg a szabadságéval. A szabadság ugyanis - ebben a keretben - alkalmasnak tételeződik arra, hogy politikai gyakorlatok, intézkedések, törvények megitélésekor egyfajta általános iránytúként vétessék haszna (Pettit, 2014). Hogy mely gyakorlat, intézkedés vagy törvény fönntartása a helyes, mely fönntartása helytelen, eszerint azon fordul meg, hogy az adott gyakorlat, intézkedés, törvény a szabadság ügyét előmozdítja-e vagy pedig sem. Ugyanez az iránytú segít dönteni afelől is, hogy a fennálló megoldások helyén, ha azok fenntartása esetleg helytelennek minősül, miféle új megoldások kialakítása a kívánatos.

A republikánus szabadságideál nyilvánvalóan sokat kíván a politikai közösségben. A lényeget tekintve - mint többször előrebocsátottam - azt, hogy az alanyok egy sajátos státust élvezzenek, a kezükben legyen a végső kontroll egy formája az előttük álló döntési helyzetekben. De mit jelent ez konkrétabban? A republikánus irodalomban kétféle föltétel szokott megjelenni. Az egyik föltétel a jó intézmények megléte: ilyen intézmény az úgynevezett vegyes alkotmány, vagy a hatalmi ágak elválasztása, a kiterjedt alapvető polgárjogok, valamint a fékek és ellensúlyok rendszere, továbbá olyan csatornák, amelyeken keresztül a honpolgárok "alulról” szerveződve is hatékonyan tudják az érdekeiket érvényesíteni. A másik (nem intézményi) típusú föltétel nem más, mint a honpolgárok kollektív erőfeszítése, széleskörű politikai részvétele. A tanulmányom harmadik részében ez utóbbi föltétel kérdését vizsgálom meg. Keith, és a csak röviden érintett Odüsszeusz analógiáit a továbbiakban nem fogom alkalmazni.

A politikai részvétel helye a respublikában

„Lábam a magam szóllején tapos, / túl kényelmes valék mindég, akármi / gyúlésre, avagy dühödt klubba járni, /és nem kívántam soha zavaros / eszméknek élni, sírig hü cseléd, - / Istent, anyámat s a kedvest szolgáltam;"

(Alfred de Musset: Óda a sajtótörvényhez. Faludy György fordítása)

Egy elgondolás szerint - amelynek a legközismertebb megfogalmazásait talán Arisztotelész és Hannah Arendt írásaiban találjuk - a fönti rövidke versszak már elegendő bizonyítéka is annak, hogy Musset nem szabad (Arisztotelész, 1984; Arendt, 1991: 37.). Egy másik elképzelés ennek az ellentétét állítja. Előb- 
bi megfeleltethető az erős, vagy görög, utóbbi a gyenge, vagy római republikánus értelmezésnek. Itt mindjárt érdemes volna egy gyakran előforduló félreértést eloszlatni: a szabadság és a politikai részvétel összefüggésének kérdése, azt hiszem nem, vagy csak lazán kapcsolódik a jó intézmények kérdéséhez. Nem értek tehát egyet azokkal, akik az erős értelmezésből - ahogy van - a lehető legszélesebb körú részvételnek utat nyitó intézményi megoldások - a választásokon való kötelező szavazás, a referendumok, a falugyưlések, és egyéb deliberatív fórumok - kívánatosságát vezetik le, míg a gyenge értelmezésből a részvételnek jóval szúkösebb teret hagyó, a szabadság védelmét inkább a közvetlenül meg nem választott bíróságokra és jogvédőkre bízó megoldások kívánatosságát (Honohan, 2002: 197.). Annak ellenére sem, hogy az erős értelmezés szerzői jobbára csakugyan az előbbi, a gyenge értelmezés szerzői pedig az utóbbi megoldások irányába szoktak hajlani (Pettit, 1997 és 2012). Valójában ugyanis nincs szükségszerü logikai összefüggés a két kérdés között. Míg az erős értelmezés - tagadhatatlanul - csakis a részvételnek a lehető legszélesebb teret biztosító megoldásokkal fér meg, addig a gyenge, túl azon, hogy összeegyeztethető ezek elvetésével is, nem föltétlenül zárja ki őket. Minden további nélkül állíthatjuk például, hogy a politikai részvétel a szabadság megőrzésének csupán eszköze, ám mint ilyen, igenis megkerülhetetlen. Ha nem tévedek tehát, a politikai részvétel és a szabadság közötti összefüggés firtatása, ennyiben végső soron csakis a szabadság és a részvétel mibenlétéről, valamint értékességéről szól, és semmi egyébről.

\section{Mi a politikai részvétel?}

A politikai részvétel respublikában sokféle terepen lehetséges: szavazófülkékben a referendumok során, vagy a központi törvényhozó testületek és a helyi önkormányzatok megválasztásakor, a falusi, városi és kerületi gyúléseken, esetleg egyéb deliberatív fórumokon, aztán pártok irodáiban, jogvédő szervezetekben, ombudsmani hivatalokban, akár bírósági fórumokon, újságok hasábjain, az utcán, a közösségi médiában és így tovább. A legáltalánosabb értelemben a politikai részvétel valamiféle realizált, cselekvő bekapcsolódást jelent a politikai gyakorlatok formálásába, a közösségi önkormányzatba. Ez persze föltételez bizonyos dolgokat, így például hozzávetőleges egyetértést a tagság kérdéséról - arról, ki tartozik egyáltalán a respublika közösségéhez -, kölcsönös elismerést, továbbá egymás igényeinek bizonyos fokú tekintetbe vételét, olyan körülményeket, amelyek közt a honpolgárokat meg is hallgatják (Maynor, 2003: 53.). Másfelől viszont ugyanezeknek a honpolgároknak képeseknek kell lenniük jelezni, vagy szólni, ha valami mondjuk nincs az ínyükre. Ebben rejlik a republikánus szabadságideál diskurzív oldala (Pettit, 2001: 65-78.; Schuppert, 2013; Markell, 2008). 
Empirikus adottság, hogy a politikai részvétel a legtöbb létező és valaha létezett emberi társadalomban a többségnek nem, vagy csak nagyon korlátozott mértékig kenyere. A honpolgárok szívesebben múvelik meg a kertjeiket - vagy ha úgy tetszik, taposnak a saját szőlőjükön - a közjó előmozdítása helyett, és aki részt vesz, az sem szívesen vesz részt minden ôt érintő gyakorlatban, legföljebb a hozzá legközelebb állóakban, és azokban is csak alkalomadtán, de nem rendszeresen (Bellamy, 2008: 162; Maynor, 2006: 134-135.). Ennek, azt hiszem, tulajdonítanunk kell némi súlyt, amikor arról gondolkodunk, milyen meggyőző normatív érvek hozhatók föl a politikai részvételnek önértéket, és a szabadság szempontjából konstitutív értéket tulajdonító erős republikánus értelmezés érdekében. Ha ugyanis a politikai részvétel a szabadság szempontjából konstitutív értékkel bír, úgy, föltéve, hogy a szabadságot egyetemes ideálként kezeljük - márpedig a modern republikánusok, köztük Pettit is, így kezelik -, a politikai részvételt is egyetemessé kell tenni, a honpolgárok lehető legszélesebb körét, vagy ha lehet az összességét mozgósítva. Akár - tehetnénk hozzá - a többségi diszpozíciókat fölülírva is.

\section{A politikai részvétel, mint önérték}

Mi lehet tehát meggyőző normatív érv a politikai részvétel önértékként tételezése mellett? Bizonyosan nem az, amit Sandel vet föl. A közjó, a jó kormányzás - írja - a honpolgároktól áldozathozatalt, cselekvő hozzájárulást, egyszóval politikai részvételt követel. A honpolgárok erre csakis abban az esetben lesznek hajlandóak, ha úgy tudják, az áldozatuk önértékkel bír. Ellenkező esetben ragaszkodni fognak a tulajdon szőlőjükhöz. Mert ameddig azt a bizonyos áldozatot csupán eszközértéknek tekintik, úgy számíthatunk rá, hogy folyton mérlegelni fogják, csakugyan érdemes-e meghozniuk egyáltalán (Sandel, 1998: 325.). Mármost - túl azon, hogy empirikus pszichológiai adottságként kezel olyasmit, ami valójában nagyon is kétséges - a gond ezzel az érveléssel az, hogy tartalmaz egy ellentmondást. Bár a politikai részvétel önértékét igyekszik kimutatni, azt egy külső fogalomhoz, a közjóhoz csatolja - mégpedig eszközértékként. Az összecsatolás ráadásul nem is logikai természetü, hanem stratégiai. Nem az következik belőle, hogy a politikai részvétel csakugyan önérték, hanem csak az, hogy a honpolgárok önértékként kell, hogy kezeljék.

Egy másik megoldás az, ha kiindulópontként föltesszük, a preferenciákat nem szabad - ahogy találjuk őket - reflexió nélkül elfogadnunk, hiszen ezek lehetnek indokolatlanok, vagy pedig helytelenek is bizonyos értelemben. És ha ez így van, adott esetben a szabadság belsô akadályainak is minősülhetnek (Taylor, 1985: 227.; Tallár 1999: 16.). Legalább kétféleképpen érvelhetünk ez mellett. Az elsó, ha föltesszük, a preferenciáink és vágyaink egy sajátos rendbe 
ágyazódnak. Ez a rend az úgynevezett első- és a másodrendű vágyakból áll. Az előbbiek a vágyainkat jelölik, ahogy találjuk őket. Ilyen például a falánknak az étel, vagy az iszákosnak az ital iránti sóvárgása. Utóbbiak a vágyainkkal kapcsolatos vágyainkat jelölik, úgymond. Ilyen lehet a falánk arra vonatkozó kívánsága, hogy falánksága, vagy az iszákosé, hogy csillapíthatatlan szomjúsága szűnjék meg (Frankfurt, 1982; Haworth, 1991: 134.; Christman, 1988: 112.; Balázs, 2011). Az első- és a másodrendû vágyaink közti viszonyokat többnyire persze összhang szokta jellemezni: másként nem is tudnánk élni. Mégis, előfordul, hogy feszültség áll fenn. Ilyenkor - mint az említett falánkunk, vagy iszákosunk esetében - arról van szó, hogy a tulajdon elsőrendû vágyainkkal bizonyos mélyebb értelemben mi magunk nem tudunk azonosulni, vagyis önmagunkban találjuk indokát annak, hogy a vágyainkat, vagy preferenciáinkat ne fogadjuk el reflektálatlanul, ahogy találjuk őket.

A másik fajta érvelés az, ha az azonosulás helyett a preferenciáink formálódásának a körülményeit problematizáljuk. A formálódás ugyanis soha sem semleges környezetben történik. Ellenkezőleg, a környezet mindig számos meghatározottsággal, számos adottsággal rendelkezik. Mindannyiunk számára korlátozott mennyiségú információ áll rendelkezésre, mindannyian az interszubjektivitás álláspontjából alakítjuk ki a preferenciáinkat, beleszületünk valamiféle hagyományba, fennálló jogi normák rendjébe, mindünkre hat egy sor korábbi döntés, amelyek egy része a sajátunk, másik része a környezetünkben élőké. Előfordulhat, hogy ezekből az adottságokból egy elnyomó rend adódik össze, amely félelmet szül, korlátozza a reflexiót, következésképpen pedig potenciálisan indokolatlan, helytelen vélekedések, preferenciák, vágyak kialakulásához vezet (Christman, 1991: 344-347.; Sunstein, 1993: 164-176.; Taylor, 1985: 215.; Tallár, 1999: 29-30.). Mármost összefoglalva a - kétféle ismertetett érveléssel megtámogatott - fölvetés így szól: a preferenciákat nem föltétlenül úgy kell elfogadnunk, ahogy találjuk őket, hanem csakis abban az esetben, ha valamilyen mélyebb értelemben azonosulni is tudunk velük és ha a kialakításuk körülményei nem voltak elnyomóak (Dworkin, 1981: 212.). Ez a belátás járhatott az amerikai alapító atyák fejében is - írja Sunstein -, akik pontosan egy olyan politikai rend kereteit igyekeztek kialakítani, amely a deliberációnak, a racionális reflexiónak igyekezett teret adni a meglévő preferenciák előtti főhajtás, azok puszta aggregálása helyett (Sunstein, 1993: 164.).

Mindez talán vonatkoztatható a saját szőlőnket és a politikai részvételt illető dilemmára is. Ha ugyanis a fölvetést jogosnak ismerjük el, úgy kétségesnek tünik, csakugyan fontosságot kell-e tulajdonítanunk annak az adottságnak, hogy a politikai részvétellel szemben a legtöbb létező és valaha létezett emberi társadalomban a többség a szőlő taposását részesíti, részesítette előnyben. Mert meglehet, hogy ezek a preferenciák sokak esetében feszültségben állnak másodrendú vágyakkal és a formálódásuk elnyomó környezetben ment 
végbe. Amennyiben így van, máris kevésbé tûnik terhesnek a fölülírásuk kívülről, mely bizony - láttuk - elkerülhetetlen, ha a politikai részvételnek önértéket, és az egyetemes ideálként kezelt szabadság szempontjából konstitutív értéket tulajdonítunk.

Legalább három intuíció szól egy ilyen fölfogás, illetve a rá építkező erős republikánus értelmezés mellett. Az első az, hogy a dominancia hiányaként értett szabadság státusa, vagyis az önkényes beavatkozásokat lehetővé tevő, félelemkeltő hatalmi egyenlőtlenségek fölszámolása talán definíció szerint magába foglalja a honpolgárok realizált, cselekvő bekapcsolódását a politikai gyakorlatok formálásába. Elvégre a megközelítőleges hatalmi egyenlőség, a végső kontroll birtoklásának mi képezhetné erősebb garanciáját, mint maga a bekapcsolódás, a folyamatos jelenlét - teljességgel kizárva, hogy a döntéseket a "fejünk fölött" hozzák meg? Másodszor az is valószínünek tünik, hogy sok, a politikai részvételt illető létező preferencia csakugyan feszültségben áll másodrendú vágyakkal és a formálódása elnyomó környezetben ment végbe. Ezzel összefüggésben, és részint ebből következően nem is autonóm, hiányolja a konzisztenciát, és a racionalitást (Christman, 1991: 350.; Forst, 2005: 230.). Harmadrészt az is föltehető, hogy ha főt hajtunk az efféle inkonzisztens, irracionális, gyakran hiányos információk nyomán kialakított preferenciák előtt, a közjó is súlyos csorbát szenvedhet. Vonatkoztatható ez utóbbi intuíció a közpolitikai területek többségére (Sunstein, 1993: 175.), sőt akár magára a politikai részvételre is, igaz - láttuk Sandel kapcsán - szigorúan nem érinti a szabadság és a politikai részvétel fogalmi összefüggését.

Mégis, a preferenciák fölülírhatóságát valló fölfogással és közvetve a rá építkező erős republikánus értelmezéssel szemben fölhozhatóak bizonyos ellenvetések. Mondjuk az, hogy nehéz elvileg meghatározni, pontosan mely preferenciák, mely vágyak tartoznak az el nem fogadhatóak, illetve fölülírandóak halmazába. Nyilvánvaló, hogy a rabszolga tudata elnyomó körülmények terméke, és indokolt lehet az autonómia hiányáról beszélni. De mikor még? Vannak problematikus esetek. A nacionalisták egy része például hajlamos úgy vélni, ha az általuk képviselni kívánt csoport - a nemzet - fiai nem kívánnak velük tartani, az csakis azért lehet, mert ezeket a fiakat megtévesztették, vagy pedig mert a tudatuk hamis. Következésképpen hát fölülírható, fölülírandó. Mit kezdjünk az efféle vélekedésekkel? Hogy egy preferencia kialakításának körülményei ne legyenek elnyomóak - láttuk - az egyik minimális követelmény az, hogy rendelkezésre álljon minden releváns információ. De ezzel még korántsem léptünk elörébb, hiszen nem mondtunk arról semmit, hogy az egyes preferenciák - illetve választási helyzetek - kialakítása esetében mi minden minősülhet releváns információnak, és mi nem. Egyáltalán nem magától értetődő a válasz. Azért sem, mert az információt nem lehet „kilóra mérni”, és azért sem, mert az egyes információmorzsák bizony eltérő döntések, eltérő preferenciák kialakítása felé hathatnak. 
Adná magát a megoldás, hogy ezúttal is a dominancia hiányaként értett szabadságot kezeljük morális iránytûként, amikor az egyes preferenciák elvagy el nem fogadhatóságáról kell ítélnünk, ugyanúgy, mint a politikai gyakorlatok, intézkedések, vagy a törvények esetében. Hogy melyik fönntartása a helyes, melyiké helytelen - láttuk -, a republikánus fölfogás szerint azon fordul meg, hogy adott gyakorlat, intézkedés, vagy törvény a szabadság ügyét előmozdítja-e vagy pedig sem. Vonatkoztathatjuk-e ugyanezt a módszert a preferenciákra is? Például mondhatjuk-e, hogy egy-egy preferencia elfogadhatóságának azon kell megfordulnia, hogy a formálódásának a körülményeit dominálta-e valamilyen cselekvő, vagy pedig cselekvők csoportja? Azt hiszem, nem. Egyfelől azért nem, mert a dominancia körülményei között formálódott preferenciák nyilvánvalóan nem mindig képezik le ugyanezt a dominanciát: gondoljunk csak a szabadságvágyra, amely alighanem a legelnyomóbb politikai közösségekben is valamilyen fokig jelen van, és amely bizonyos esetekben így az el nem fogadható preferenciák halmazába kerülne. Másfelől azért sem, mert ez a megoldás - föltéve, hogy az erős republikánus értelmezés keretei között maradunk - a saját szőlőnket és a politikai részvételt illető dilemmára nézve teljesen használhatatlan. Az adódna belőle, hogy végső soron nem is dilemmával van dolgunk, hiszen a részvétellel kapcsolatosan autonóm, elfogadható preferenciát csakis akkor vagyunk képesek formálni, ha ténylegesen részt is veszünk, lévén, hogy a dominancia hiányát - láttuk - maga a részvétel konstituálja. Ez a végkövetkeztetés gyanúsan körbe forog, hiszen teljesen kizárja annak a lehetőségét, hogy esetleg autonóm módon arra jussunk, inkább a tulajdon szőlőnket részesítjük előnyben. Akár azt is mondhatnánk, depolitizál: föltételezi, hogy optimális körülmények között csakis egy vélekedést tehetünk a magunkévá.

\section{A politikai részvétel, mint eszközérték}

A gyenge republikánus értelmezés keretei között ez az intuíciónkkal meglehetős feszültségben álló végkövetkeztetés elkerülhető. Ha ugyanis a realizált politikai részvételt a szabadság státusával nem azonosítjuk, csupán annak fontos - eszközeként tekintünk rá, abból az is következik, hogy nemcsak a résztvevők, hanem a saját szőlőjüket taposók is formálhatják szabadon a - részvétellel kapcsolatos - preferenciáikat. Mi több, problematizálhatóvá válik az összefüggés egy másik értelemben is. Jelesül, föl tudjuk vetni, hogy részt venni nemcsak egészen autonóm, hanem mondjuk kevésbé autonóm módon is lehet, sőt, akár úgy is, mint a ",birka” - ha szabad így mondanom (Dagger, 2005: 197199.). Elnyomó körülmények hiányában is különbözőek leszünk hajlandóság, képesség és ügyesség dolgában - például eltérő mennyiségű idôt fogunk a releváns információk megismerésének szentelni -, így hát a részvételünk is el- 
térő mértékig lesz átgondolt, racionális és így tovább. Nem is lesz minden egyes honpolgár részvételének minden ügyben hozzáadott értéke a közjó szemszögébôl nézve, következésképpen az sem tûnik magától értetődőnek, hogy a több részvétel mindig jobb volna, mint a kevesebb (Brennan-Lomasky, 2006: 231233.; Bellamy, 2008: 162.). Ennek a fölvetése azért hat annyira banálisan, mert alighanem teljesen jól illeszkedik a köznapi tapasztalatunkhoz. Amiből persze - utaltam rá az előszóban - korántsem következik, hogy a gyenge republikánus értelmezés filozófiailag igaz is volna. Könnyen lehet, hogy a dominancia hiányaként értett szabadságot valóban csakis a politikai gyakorlatok formálásába való realizált, cselekvő bekapcsolódás konstituálhatja, következésképpen pedig az autonóm preferenciaformálás is csak ennek nyomán lehetséges. Hogy ez így van-e, vagy sem, arra végső felelet nem adható.

A gyenge értelmezés két további vonzó sajátossággal rendelkezik. Egyfelől megengedi, hogy a politikai közösségen belül a republikánus honpolgárság státusának fönntartása ne föltétlenül mindenki, hanem mondjuk csak a többség részvétele mellett legyen lehetséges. Vagyis megengedi, hogy Musset hozzáférését a szabadság tárgyaihoz minden relevánsnak tételezett területen - esetünkben az alapvető polgárjogait - helyette esetleg a kertszomszédjai is megvédelmezhessék. Ha némely honpolgárok kellő erőfeszítést tesznek - szól az érvelés -, úgy mások számára nyugodtan meghagyható a szőlő taposásának a lehetősége. Másfelől, a gyenge értelmezés vonzó sajátossága az is, hogy - az erôs értelmezéshez hasonlatosan - egyáltalán nem zárja ki az egyéni preferenciák esetleges felülvizsgálhatóságát, vagy megvitathatóságát. Ugyanakkor azt már igen, hogy ezek a preferenciák - a részvétel tekintetében - optimális körülmények között csakis egyfelé tendálhatnának.

\section{ZÁRSZÓ}

A fenti tanulmányban, ahogy előrebocsátottam, két fogalom - a szabadság és a politikai részvétel - logikai összefüggésének a vizsgálatán keresztül, a politikai részvétel értékességéről szóltam. Nem állítottam, hogy a részvételnek önértéket tulajdonító republikánus értelmezés filozófiailag igaz, az eszközértéket tulajdonító értelmezés pedig hamis volna. Mindkettő rendelkezik némi intuitív erővel és nem is hiszem, hogy a rendelkezésünkre állna végső felelet a dilemma megoldására. Ennek megállapításánál sokkal többre nem is juthatunk. Nem véletlen, hogy maga Pettit is a szabadság ontológiai magyarázatairól szóló értekezéseiben rendszerint az intuícióra utal vissza (Pettit, 1997; 2001; 2012; 2014). Hogy a szabadság pontosan micsoda, mi konstituálja, és a részvételnek milyen értéke van, legföljebb csak intuitíve sejthetjük, de egészen biztosan nem tudhatjuk sohasem. 


\section{JEGYZETEK}

1 Jelen publikáció az Európai Unió, Magyarország és az Európai Szociális Alap társfinanszírozása által biztosított forrásból az EFOP-3.6.3-VEKOP-16-2017-00007 azonosítószámú Tehetségból fiatal kutató - A kutatói életpályát támogató tevékenységek a felsőoktatásban címú projekt keretében jött létre.

2 A magyar nyelvben nincs pontos fordítása a bully angol kifejezésnek, jobb híján a „zsarnokot” használom. A kistermetû Keith-t terrorizáló erős fiút értem alatta.

3 Arról nem szólva, hogy a republikánus és a liberális elméletek eltérése nemcsak a szabadság fogalmának a tekintetében áll, vagy állhat.

\section{IRODALOM}

Andronache, Laura (2006): Contemporary Republican Theories: in Search of Solidarity. In: HonohanJennings (szerk.): Republicanism in Theory and Practice. New York, Routledge.

Arendt, Hannah (1991): A forradalom. Budapest, Európa Könyvkiadó.

Arisztotelész (1984). Politika. Budapest, Gondolat.

Balázs Zoltán (2011): A szabad akarat hierarchikus elmélete. In: A jó vonzásában. Budapest, Helikon Kiadó.

Bellamy, Richard (2008): Republicanism, Decomcracy, and Constitutionalism. In: Republicanism and Political Theory. Oxford, Laborde-Maynor, Blackwell.

Berlin, Isaiah (1990): Négy esszé a szabadságról. Budapest, Európa Könyvkiadó.

Brennan, Geoffrey-Lomasky, Loren (2006): Against reviving republicanism. Politics, Philosophy \& Economics, 5, 220-252. https://doi.org/10.1177/1470594x06064224

Christman, John (1988): Constructing the Inner Citadel: Recent Work on the Concept of Autonomy. Ethics 1, 109-124. https://doi.org/10.1086/293038

Christman, John (1991): Liberalism and Individual Positive Freedom. Ethics, 2, 343-359. https:// doi.org/10.1086/293292

Dagger, Richard (2005): Autonomy, Domination, and the Republican Challenge to Liberalism. In: Autonomy and the Challenges to Liberalism - New Essays. Cambridge, Cambridge University Press. https://doi.org/10.1017/cbo9780511610325.010

Dworkin, Gerald (1981): The Concept of Autonomy. In: Haller, Rodopi (szerk.): Science and Ethics, Amsterdam, 203-213. https://doi.org/10.5840/gps198112/1333

Forst, Rainer (2005): Political Liberty: Integrating Five Conceptions of Autonomy. In: Autonomy and the Challenges to Liberalism - New Essays. Cambridge, Cambridge University Press. https:// doi.org/cbo9780511610325.012

Frankfurt, Harry G. (1982): Freedom of the Will and the Concept of a Person. In: Free Will. Oxford, Watson-Oxford University Press.

Haworth, Lawrence (1991): Dworkin on Autonomy. Ethics, 1, 129-139. https://doi.org/10.1086/293375 Hobbes, Thomas (1970): Leviatán. Budapest, Magyar Helikon.

Honohan, Iseult (2002): Civic Republicanism. New York, Routledge. https://doi.org/10.4324/978020 3460894 
Larmore, Charles (2001): A Critique of Philip Pettit's Republicanism. Philosophical Issues, 11, 229_ 243. https://doi.org/10.1111/j.1758-2237.2001.tb00045.x

MacCallum, Gerald C. (1967): Negative and Positive Freedom. The Philosophical Review, 3, 312-334. https://doi.org/10.2307/2183622

Marcus Aurelius (1975): Marcus Aurelius elmélkedései. Budapest, Európa Könyvkiadó.

Markell, Patchen (2008): The Insufficiency of Non-Domination. Political Theory, 1, 936. https://doi. org/10.1177/0090591707310084

Maynor, John (2003): Republicanism in the Modern World. Oxford, Polity.

Maynor, John (2006): Modern Republican Democratic Contestation: a Model of Deliberative Democracy. In: Republicanism in Theory and Practice. New York, Routledge.

Parekh, Bhikhu (1992): The Cultural Particularity of Liberal Democracy, Political Studies, 40, 160 175. https://doi.org/10.1111/j.1467-9248.1992.tb01819.x

Patten, Alan (1996): The Republican Critique of Liberalism, British Journal of Political Science, 1, 25-44. https://doi.org/10.1017/s0007123400007407

Pettit, Philip (1997): Republicanism - a Theory of Freedom and Government. Oxford, Oxford University Press. https://doi.org/10.1093/0198296428.001.0001

Pettit, Philip (2001): A Theory of Freedom - From the Psychology to the Politics of Agency. Oxford, Oxford University Press.

Pettit, Philip (2012): On the People's Terms - a Republican Theory and Model of Democracy. Cambridge, Cambridge University Press. https://doi.org/10.1017/cbo9781139017428

Pettit, Philip (2014): Just Freedom: a Moral Compass for a Complex World. New York, W. W. Norton.

Sandel, Michael (1998): Reply to Critics. In: Debating Democracy's Discontent. Oxford, Oxford University Press. https://doi.org/10.1093/0198294964.003.0025

Schuppert, Fabian (2013): Discursive control, non-domination and Hegelian recognition theory: Marrying Pettit's account(s) of freedom with a Pippinian/Brandomian reading of Hegelian agency. Philosophy and Social Criticism, 9, 893-905. https://doi.org/10.1177/0191453713498389

Skinner, Quentin (1998): Liberty before Liberalism. Cambridge, Cambridge Univeristy Press.

Skinner, Quentin (2008): Freedom as the Absence of Arbitrary Power. In: Republicanism in Political Theory. Oxford, Blackwell Publishing.

Sunstein, Cass R. (1993): The Partial Constitution. Cambridge, Harvard University Press.

Tallár Ferenc (1999): Szabadságra kényszerítés? In: A szabadság és az európai tradíció. Budapest, Atlantisz.

Taylor, Charles (1985): What's Wrong with Negative Liberty. In: Philosophical Papers 2, Cambridge, Cambridge University Press.

Tully, James (1995): Strange Multiplicity. Cambridge, Cambridge University Press. https://doi. org/10.1017/cbo9781139170888

Viroli, Maurizio (1995): For Love of Country - an Essay on Patriotism and Nationalism. Oxford, Oxford University Press.

Viroli, Maurizio (2002): Republicanism. New York, Hill and Wang.

Wall, Steven (2001): Freedom, Interference and Domination, Political Studies, 2, 216-230. https:// doi.org/10.1111/1467-9248.00310 